\title{
EngagedScholarship@CSU
}

Civil and Environmental Engineering Faculty

Publications

Civil and Environmental Engineering

7-2001

\section{Lessons from Roman Cement and Concrete}

Norbert J. Delatte

Cleveland State University, n.delatte@csuohio.edu

Follow this and additional works at: https://engagedscholarship.csuohio.edu/encee_facpub

Part of the Civil Engineering Commons, and the Hydraulic Engineering Commons

How does access to this work benefit you? Let us know!

Publisher's Statement

(C) ASCE

\section{Original Citation}

Delatte, N. (2001). "Lessons from Roman Cement and Concrete." J.Prof.Issues Eng.Educ.Pract., 127(3), 109-115.

This Article is brought to you for free and open access by the Civil and Environmental Engineering at EngagedScholarship@CSU. It has been accepted for inclusion in Civil and Environmental Engineering Faculty Publications by an authorized administrator of EngagedScholarship@CSU. For more information, please contact library.es@csuohio.edu. 


\title{
Lessons from Roman Cement And Concrete
}

\author{
By Norbert J. Delatte, ${ }^{1}$ Member, ASCE
}

\begin{abstract}
Although masonry and lime mortars had been used for centuries by earlier civilizations, the Romans were the first to extensively use naturally occurring volcanic earth to make hydraulic cement. The volcanic powder named "pulvis puteolanis," found near the town of Puteoli near Naples (now Pozzouli), was used to build magnificent structures. The use of this hydraulic cement in masonry and concrete greatly expanded civil engineering possibilities. The Roman engineer Vitruvius, writing in The Ten Books on Architecture, described the careful materials selection, proportioning, and workmanship that was critical to the performance of Roman concrete. Masonry and coarse and fine aggregates were carefully selected for durability. Hydraulic cement concrete was used extensively for constructing bridge piers and harbor jetties. One of the greatest examples of Roman concrete construction was the dome of the Pantheon, with its 43.4$\mathrm{m}$ span. The vast system of aqueducts also made extensive use of hydraulic cement. This paper summarizes the materials and construction methods used in Roman concrete construction, as well as structures and infrastructure built with concrete.
\end{abstract}

\section{INTRODUCTION}

As engineers struggle with the difficult task of rehabilitating deteriorating infrastructure, there may be lessons to learn from the satisfactory long-term performance of ancient concrete structures. The Pantheon in Rome, with its magnificent 43.4-m concrete dome (Figs. 1-3), built by Agrippa in about 118-125 A.D., has quitely stood for nearly two millennia with only minor repairs (Adam 1994). It continues in use today despite damage by fire during Trajan's reign and the theft of tiles, marble facings, and bronze roof girders in the ensuing centuries (De Camp 1980).

Concrete has proved more durable than other building materials that the Romans used. "It is the interior concrete cores of walls, columns, slabs, etc. and brickwork with cementing mortar which have survived to our time, where the cladding facades of marble or stone masonry have disappeared" (Idorn 1997, p. 18). De Camp discusses the value of concrete to Roman infrastructure, stating, "here for the first time was a completely satisfactory waterproof concrete, which formed a synthetic rock as hard as most natural rocks. In fact, samples of Roman concrete that have come down to modern times in buildings, conduits, and the like are harder than many natural rocks would be after so many centuries of exposure" (De Camp 1980, p. 183).

Much of what we know about Roman building materials and methods comes from Marcus Vitruvius Pollo, or Vitruvius, who wrote The Ten Books on Architecture in the first century B.C. In this single work, Vitruvius gathers together specification information, construction guidelines, and design principles, with interesting digressions into other topics. He pointed out that, although in his day it was customary to set the useful life of construction at 80 years, it was possible with care to build structures that would last longer (Vitruvius 1960).

When Vitruvius was writing, concrete was still being used sparingly and tentatively, because it was a relatively recent innovation. The earliest dated concrete structure is from about 121 B.C. and is of poor quality, but later structures were much more durable (White 1984). Many of the later structures were described in detail and sketched by Andrea Palladio in The Four Books of Architecture, published in 1570 and translated by Isaac Ware into English in 1738 (Palladio 1965).

\section{MATERIALS AND SPECIFICATIONS}

The Romans used a wide variety of construction materials, but they were pioneers in the wide-scale use of hydraulic cement. Vitruvius states, "There is also a kind of powder which from natural causes produces astonishing results. It is found in the neighborhood of Baiae and in the country belonging to towns round about Mt. Vesuvius. This substance, when mixed with lime and rubble, not only lends strength to buildings of other kinds, but even when piers of it are constructed in the sea, they set hard under water" (Vitruvius 1960, pp. 46-47). Our modern word Pozzolan or Pozzolana comes from the town of Pozzuoli, north of Naples, where many of these deposits were found. De Camp (1980, p. 182) suggests that the Romans discovered and began to use this material in about the third century B.C. Hill (1997, p. 106) states the following about pozzolana: "its use made possible the construction of the impressive vaults and domes over the public baths, and it was a valuable material for the piers of bridges, and in harbour works." Hill suggests that pozzolana was also found in the Alban Hills, just south of Rome. Idorn (1997) tells us that the Greeks, up to two 


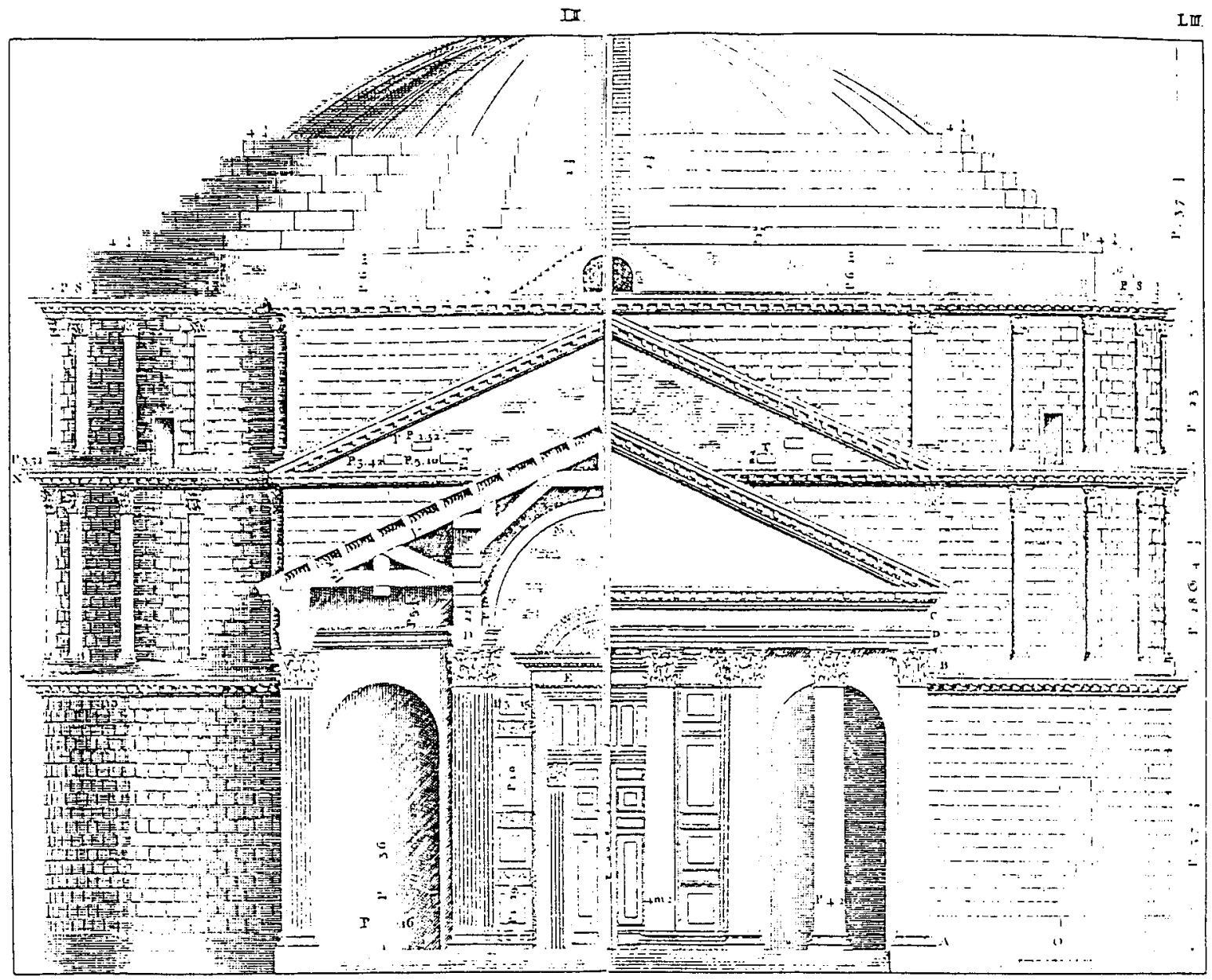

FIG. 1. The Pantheon in Rome (Palladio 1965)



FIG. 2. Pantheon in Rome, Interior View (Most of the Decoration Restored). (From http://www.bowdoin.edu/dept/clas/arch102/hadrian/ pantheon.intl.html, used with permission)

centuries earlier, had used a highly siliceous volcanic Satorin earth.

The use of lime mortar was much older. Adam (1994) states that lime plaster was used in Asia Minor (Ç atal Hüyük) as early as the sixth millennium B.C. but that the use of lime as mortar for binding stones seems to have first appeared in Egypt in the third millennium B.C. "Lime (calx in Latin from which is derived the word calcium in English) is obtained by the calcination (a word of the same etymology) of limestone at around $1000^{\circ} \mathrm{C}$, 


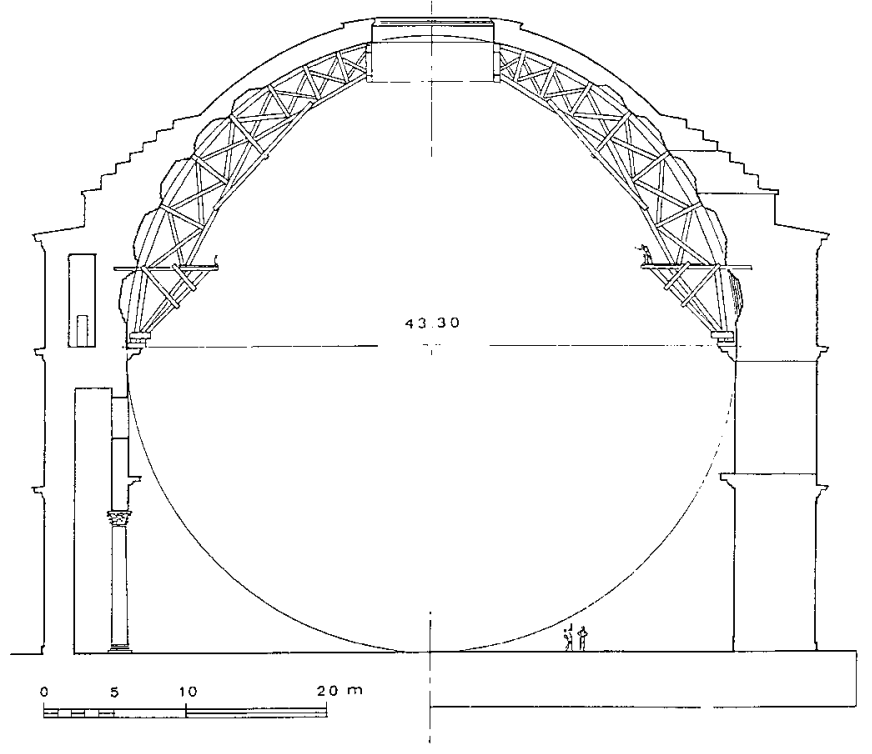

FIG. 3. The Pantheon (Adam 1994)

during which it releases its carbon dioxide. The chemical equation for the calcination of pure limestone can be expressed as follows:

$\mathrm{CaCO}_{3} \quad \rightarrow \quad \mathrm{CO}_{2}+\mathrm{CaO}$

calcium carbonate calcination carbon dioxide and calcium oxide

The resulting product, an oxide of calcium, is called quicklime, a stone with a crumbly surface which can be hydrated to obtain a bonding agent. This hydration, or slaking, is achieved by immersion and brings about the decomposition of the blocks, which expand, give off a strong heat and form a putty which is the slaked lime" (Adam 1994, p. 65). Adam (1994, p. 70) quotes Cato writing about 160 B.C. describing the Roman manufacturing process in detail. Vitruvius $(1960$, p. 45$)$ states that the selection of the stone for burning is important, with closegrained hard stone better for mortar and porous stone better for stucco. The difference is that for the first application, strength is important, and for the second, a lack of shrinkage to prevent cracking is important.

The other ingredient of mortar is sand. Vitruvius prefers pitsand to river or sea sand and suggests that the best sand crackles when rubbed in the hand. He also suggests a primitive test for clay and objectionable material"throw some sand upon a white garment and then shake it out; if the garment is not soiled and no dirt adheres to it, the sand is suitable" (Vitruvius 1960, p. 44). River sand makes mortar that dries more slowly, thus leading to interruptions in construction. Sea sands could lead to a salty efflorescence when used in stucco. He states his sand "specification" as follows: "But pitsand used in masonry dries quickly, the stucco coating is permanent, and the walls can support vaultings. I am speaking of sand fresh from the sandpits. For if it lies unused too long after being taken out, it is disintegrated by exposure... So when mixed in masonry, it has no binding power on the rubble,
TABLE 1. Mortar Composition (Vitruvius 1960; Adam 1994)

\begin{tabular}{|c|c|c|c|}
\hline $\begin{array}{l}\text { Bonding } \\
\text { agent }\end{array}$ & Aggregate & $\begin{array}{l}\text { Water } \\
(\%)\end{array}$ & Comment \\
\hline $\begin{array}{l}1 \text { part of } \\
\text { lime }\end{array}$ & $\begin{array}{l}3 \text { parts of quarry } \\
\text { sand }\end{array}$ & $15-20$ & \\
\hline $\begin{array}{l}1 \text { part of } \\
\text { lime }\end{array}$ & $\begin{array}{l}2 \text { parts of river } \\
\text { sand }\end{array}$ & $15-20$ & \\
\hline $\begin{array}{l}1 \text { part of } \\
\text { lime }\end{array}$ & $\begin{array}{l}2 \text { parts of river } \\
\text { sand, } 1 \text { part } \\
\text { broken tile } \\
\text { fragments }\end{array}$ & $15-20$ & $\begin{array}{l}\text { Preferable if river sand } \\
\text { must be used }\end{array}$ \\
\hline $\begin{array}{l}1 \text { part of } \\
\text { lime }\end{array}$ & $\begin{array}{l}2 \text { parts of poz- } \\
\text { zolana }\end{array}$ & $15-20$ & $\begin{array}{l}\text { Hydraulic mortar for } \\
\text { marine construction }\end{array}$ \\
\hline
\end{tabular}

which consequently settles and down comes the load which the walls can no longer support. Fresh pitsand, however, in spite of all its excellence in concrete structures, is not equally useful in stucco, the richness of which ... will cause it to crack as it dries on account of the great strength of the mixture" (Vitruvius 1960, p. 45). Thus we see one specification of sand when the strength of the mortar is important and another when resistance to shrinkage cracking is important. Vitruvius understood the need to specify different materials for different applications.

Vitruvius suggested four different possible formulations for mortar, based on the available materials shown in Table 1. The use of broken brick or tile fragments to improve the bonding strength of mortar was common. Burned brick and tile from the fire of 64 A.D. in Nero's reign was incorporated into concrete used to rebuild Rome (White 1984, p. 86).

The mortar was used to bind either bricks or stones. Mud brick and stone had been used for some time before the Roman period (De Camp 1980; Adam 1994). Vitruvius (1960, pp. 42-43) carefully states the materials and manufacturing processes for quality dried brick. "They should not be made of sandy or pebbly clay, or of fine gravel, because when made of these kinds they are in the first place heavy; and, secondly, when washed by the rain as they stand in walls, they go to pieces and break up, and the straw in them does not hold together on account of the roughness of the material. They should rather be made of white and chalky or red clay, or even of a coarse grained gravelly clay. These materials are smooth and therefore durable; they are not heavy to work with, and are readily laid." He goes on to state the measures that should be taken to avoid shrinkage-make bricks in spring or autumn, not summer, and allow them to dry thoroughly for two years.

Baked or fired bricks were in use in southern Italy at this time, but Vitruvius does not mention them. This may have been because of the high quality and abundance of available building stone (White 1984). Baked bricks were often marked with a manufacturer's stamp, and these stamps have been used to attempt to date the Pantheon (Adam 1994, p. 183). Vitruvius (1960, p. 57) suggests that burnt bricks that have been used as roofing tiles and have given satisfactory service should be reused in walls, because they have been proven to be durable. 
The building stone available in Italy included volcanic tufas, limestones, and marbles (White 1984). Vitruvius (1960, p. 50) discusses at length the quality of stone available from different quarries. He is particularly concerned with the durability and fire resistance of the available stone. As a test of durability, he suggests quarrying the stone in summer and leaving it exposed to the elements for 2 years. If the stone is weathered, it should then only be used below ground in foundations, but stone that is still sound can now be used in the structure.

The recommendations of Vitruvius on materials selection may be stated as follows:

- Not all available materials are suitable for construction. When possible, materials from proven sources should be used.

- In the absence of a proven source, the engineer should know what properties are desirable and have test methods to determine which materials are likely to lead to durable construction.

- Some materials are better than others for specific applications.

- Durability should be the first consideration in material selection.

- Economy is best served by using locally available materials, provided they meet specifications.

- Sand quality is important for durable mortars and concretes.

- Shrinkage of mortars and unbaked bricks should be considered.

\section{CONSTRUCTION METHODS AND QUALITY CONTROL}

In early Rome, as in other parts of the Mediterranean, construction with large stone blocks was common. This type of construction was particularly important for fortifications. However, it presented a number of difficulties. One was the difficulty of transporting large blocks and raising them into position. A number of devices were used to try to make this easier. Another was the need to shape and dress stones, often requiring skilled labor. Even as the need for fortifications decreased, stone blocks remained popular for important, monumental works such as temples and palaces. Metal clamps were often used to lock blocks together. Many of these were stolen after the fall of Rome (White 1984; Adam 1994).

Roman masonry building techniques had several advantages over large stone block construction. Masonry was much faster-Adam (1994, 80-81) contrasts the Great Temple of Apollo at Didyma, which was abandoned, incomplete, after $41 / 2$ centuries, with the Pantheon and Baths of Caracella, completed in 5 to 7 years. Standardization of building materials and techniques, improved planning of building sites, and other techniques considerably expedited construction.

White (1984) discusses the evolution of the use of concrete in Roman construction. In the time of Vitruvius, the new cement was used mostly as a superior kind of mortar. The two main uses then seem to have been for foundations and for city tenement blocks (insulae). The methods developed slowly. Idorn (1997) discusses the importance of quality control and careful construction. White (1994, pp. 204-205) notes "the development and application of concrete mixes of varying composition and appropriate strength rank among the most outstanding contributions of the Romans to structure." He later addresses the importance of workmanship. "Close examination shows the amount of care given to the arrangement of the aggregates, layers of larger stones alternating with a mix consisting of broken lumps of tufa, peperino, and broken brick a cheap and economical system of construction, in which the materials were close at hand, and the waste products could be incorporated!"

Mehta and Langley (2000, p. 28) attribute the longevity of the Pantheon to "the excellent quality of the mortar in the concrete mixture, and the careful selection and grading of the aggregate material." They also note that "ancient concrete mixtures were generally characterized by low cementitious material content, low water content (consolidation was achieved by tamping), a very slow rate of strength development, and almost no shrinkage strains from cooling and drying."

The basic technique combined a core of rubble and mortar with stone facings. Different techniques of arranging the facing stones were used (Fig. 4). Vitruvius refers to two styles, the newer "opus reticulatum" and the older "opus incertum." The two facing techniques were the outer skin of "opus caementicium," referring to the core of rubble cemented together with mortar. The opus incertum used random sizes and shapes of stones, leading to a rougher appearance but stronger structure than the later technique (Vitruvius 1960). For walls covered with plaster, of course, the strength of the wall was much more important than the appearance. With this technique "these facings thus serve as the permanent framework for the material that forms the body of the wall and functions as the supporting element" (Adam 1994, p. 76).

The first technique gradually evolved through "opus quasi reticulatum" to opus reticulatum, characterized by a regular arrangement of standardized stones. Other patterns were used, including some that combined large stone blocks and masonry, either in a checkerboard pattern or with stone pillars with masonry infill walls. The latter technique was adopted from North Africa and the Carthaginians and was referred to as "opus africanum" (Adam 1994).

Vitruvius referred to a common problem with the durability of early masonry walls, brought about when porous stones absorbed too much water from the mortar and made it dry. Another problem was a poorly compacted and bonded rubble core (Vitruvius 1960, p. 51). In some buildings in Pompeii, the rubble was bonded with clay, which led to a very weak wall (Adam 1994).

The foundations of these structures were very impor- 


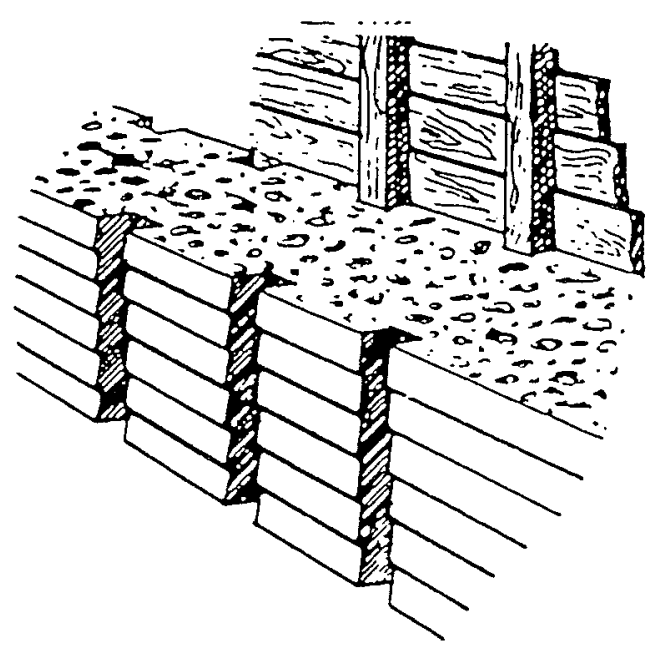

(a)

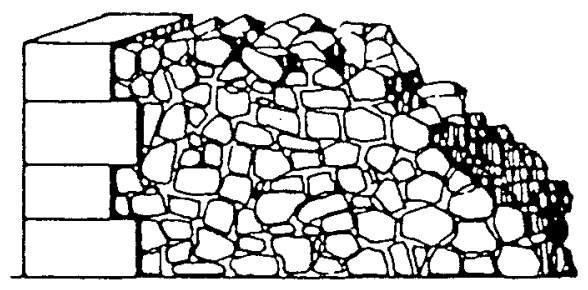

(c)

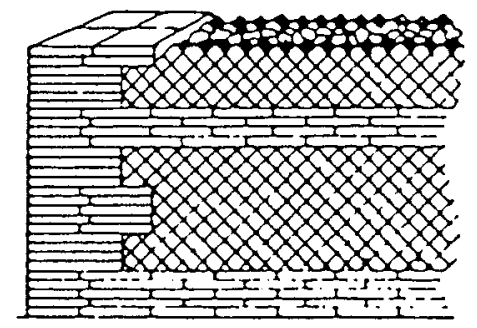

(d)

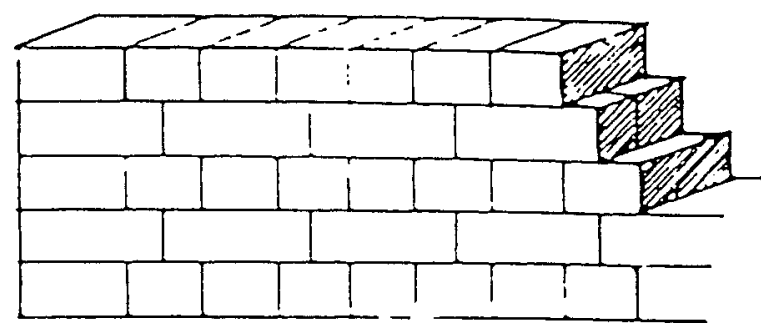

(b)

82 Types of Roman wall construction. $a$, concrete; $b$, opus quadratum; $c$, opus incertum; $d$, opus reticulatum; e, opus testaceum.

FIG. 4. Types of Walls (White 1984, p. 84)

tant, and rubble masonry bonded with lime mortar was used not only for masonry structures but also for stone block structures. Normally, footings half again as wide as the walls were used, but on some occasions wooden piles were driven (Vitruvius 1960).

The main difference between modern ready mix concrete and Roman concrete is that the Romans mixed mortar and aggregates in place and compacted it within a framework (Adam 1994). Construction of these walls required the use of scaffolding. Free-standing scaffolding was used in some cases, and in others, logs were placed through the walls in sockets and removed later (Adam 1994).

The Romans developed a system, based on the use of natural cement, which considerably improved both quality and speed of construction over earlier methods. Important features of the system included:

- use of formwork and scaffolding

- use of rubble bound by mortar made with volcanic earth cement

- careful placement of rubble in the mortar matrix

- use of recycled materials for rubble

- use of facing materials over a concrete rubble core.
Idorn (1997, p. 17) states the importance of concrete to the Romans: "In the ancient Roman empire, concrete was the fundamental basis for the lives of the populations in the big cities, and for the imperial infrastructure and commerce. Limestone and pozzolans for cement production and aggregates were abundantly available, and so were the armies of unskilled 'rope-collar' labour who could make concrete with a common performance lifetime of about 2000 years. This was achieved by rigorously imposing a standardized quality of workmanship on concrete making all over the empire."

Although in earlier stone block construction metal clamps had been used, Roman concrete construction was almost entirely unreinforced. In at least one case, the Baths of Caracalla in Rome, concrete reinforced with a copper grid was used (Gori 1999).

The lessons of Vitruvius and the other Romans on construction methods and quality control may be stated as follows:

- A reliable system of construction, combined with careful attention to workmanship, will lead to economical, durable structures.

- Careful attention to aggregate grading, packing larger 
stones with smaller aggregates, leads to stronger concrete.

- Careful use of recycled material can reduce costs while maintaining or improving quality.

- New construction methods should be developed slowly and carefully.

\section{STRUCTURES AND INFRASTRUCTURE}

The Romans developed new architectural forms such as barrel vaults and domes, based in part on the Etruscan arch. Concrete domes were cast on top of centering formwork (De Camp 1980), as shown in Fig. 3. The weight of domes was reduced by casting empty amphorae into the concrete (White 1984, p. 206).

The Pantheon is only a single example of the many Roman structures that have survived in good condition. Of particular interest in the construction of the Pantheon is the use of thinner sections and lighter aggregates (such as pumice) in the top section of the dome (Idorn 1997, p. 19). The ruins of many others, such as the Colosseum and the Baths of Caracalla, are nevertheless impressive.

The variety of structures constructed using these materials and methods remains impressive. Perhaps more important, however, was the infrastructure that tied Roman civilization together. This infrastructure comprised a transportation network of roads, bridges, and harbors, as well as a water supply network of aqueducts and dams.

Although some sources suggest that lime mortar was used in the construction of Roman roads, its use seems to have been very rare, according to archeological evidence cited by Adam (1994, p. 277). Hill (1997, p. 82), however, suggests that mortar was often used as part of the pavement structure, including hydraulic cement on the Italian peninsula. White (1984, pp. 94-95) helps resolve this issue by pointing out that Roman construction methods varied widely, based on local soil conditions and available materials, and that excavations have found hydraulic cement concrete in some roads but not in others.

Bridges were particularly important, and several have survived and are still in use today. They are easily able to carry modern traffic. Hill (1997, p. 70) describes how concrete influenced the evolution of Roman bridge construction: "Roman bridges-both for river crossings and aqueducts show a noticeable evolution in structural techniques with the passage of time. The application of concrete was a major factor in this evolution. The Pont du Gard was beautifully constructed of cut masonry blocks, and successfully reached a great height by stacking one row of arches on top of another, but the technique is clumsy and expensive. The Segovia and Tarragona bridges are good examples of the more elegant and structurally economical shapes evolved in the first century A.D. Even more refined forms developed as concrete came into wider use. In the Merida and Cherchel aqueduct bridges the 'stacking' form has disappeared the tall slender piers, constructed of concrete cores with facings of masonry and brick, are continuous from top to bottom." Bridges and aqueducts presented similar construction challenges, but grade restrictions on aqueducts were much more severe. Even for masonry bridges, hydraulic cement concrete was usually used for pier foundations.

The great aqueducts presented severe engineering and surveying challenges (Fig. 5). Rome was served by 11 , the longest 91-km long, with construction starting in 312 B.C. Only a little over $10 \%$ of the length of the aqueducts was on bridges. The longest was $132-\mathrm{km}$ long, serving Carthage. It is estimated that the aqueducts could supply 500 to $1100 \mathrm{~L}$ of water per person per day (Adam 1994). The earlier aqueducts, such as the Pont du Gard in France, were mostly masonry structures. Cement was used in later aqueducts both for construction and for lining channels (Hill 1997, p. 30).

Malinowski (1979, p. 67) notes "the canals of the un-

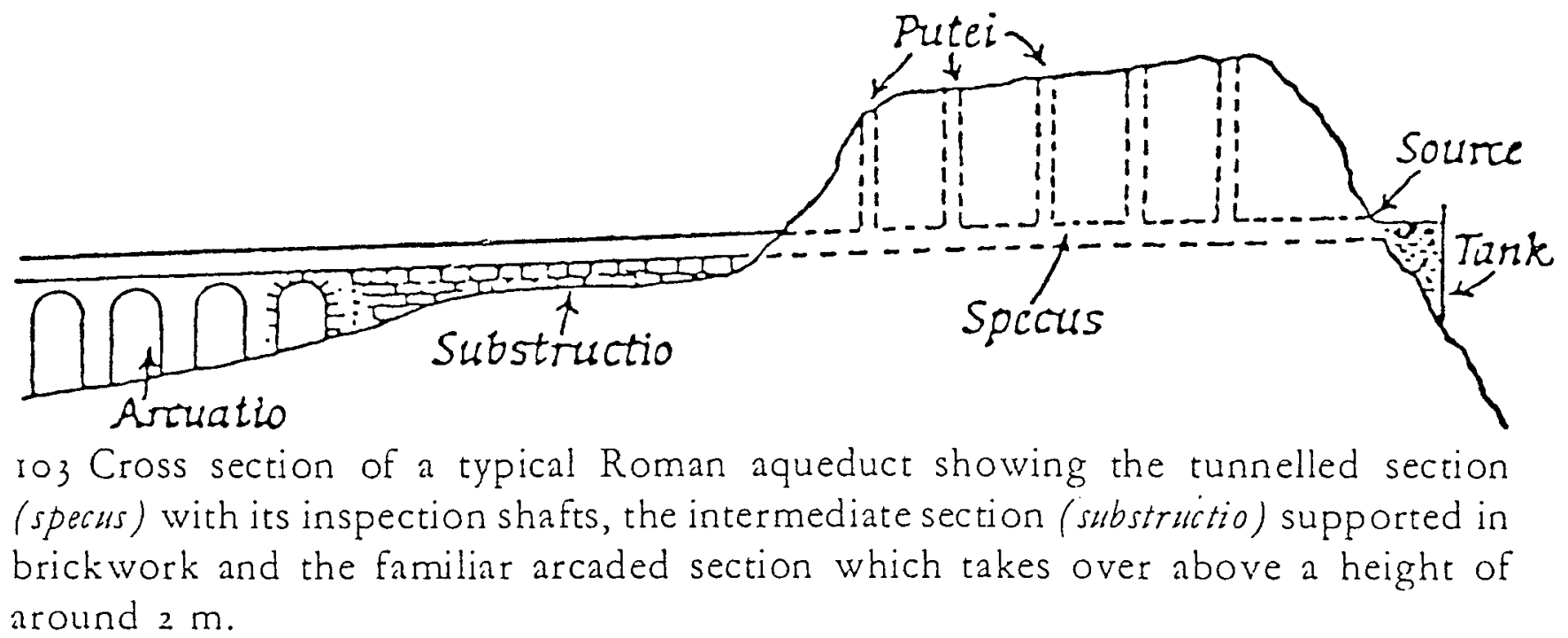

FIG. 5. Aqueducts (White 1984, p. 101) 


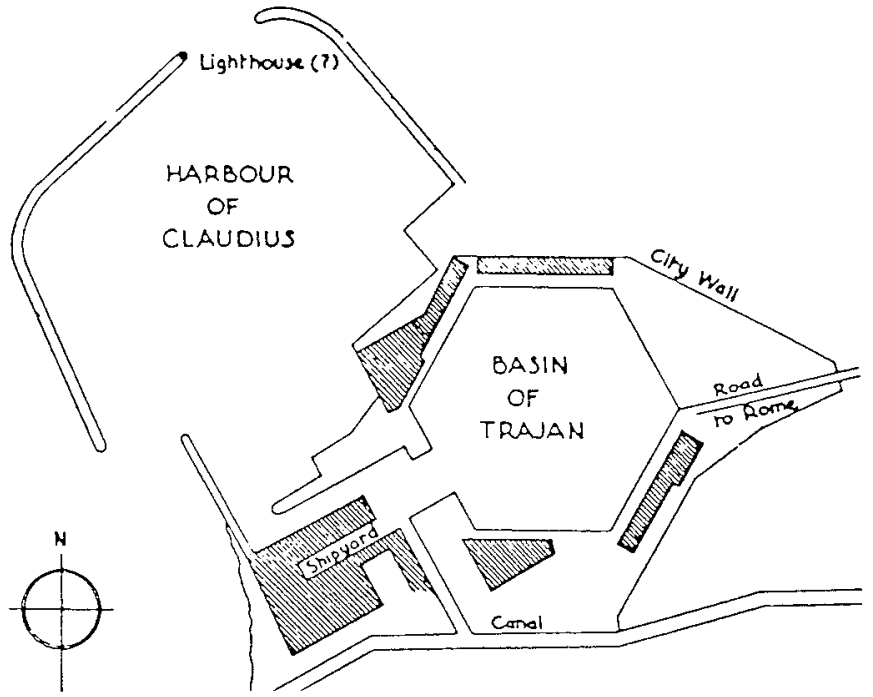

FIG. 6. The Harbor of Ostia (White 1984, p. 109)

derground and elevated aqueducts generally lacked joints, a fact which astonishes modern concrete technologists. With simple building materials and handicraft methods, the ancient builders developed techniques which ensured that the conduits would be impermeable to water, without shrinkage and cracks, and very durable." Multilayer stucco plaster was carefully polished by hand. An expanding sealant, made of lime and oil, is also described by Vitruvius (Vitruvius 1960; Malinowski 1979).

At least two dams that survive were made of masonry with concrete cores (Hill 1997, p. 54). Hydraulic cement was also particularly useful for the construction of harbor breakwaters. Cofferdams could be used unless currents or waves made them impractical. Under these conditions, Vitruvius (1960, p. 163) suggests building a large concrete block at the water's edge and toppling it into the sea and constructing the breakwater outward in this manner, one block at a time. The construction of the port of Ostia (Fig. 6), which supplied grain to feed Rome, was made possible with hydraulic cement (White 1984, p. 112). An excellent source for images of existing Roman structures may be found on the web at Dr. Higgenbotham's Bowdoin College site at http://www.bowdoin.edu/dept/clas/arch102

The lessons of Vitruvius and other Romans on the design and the construction of buildings and infrastructure may be summarized as follows:

- Standardization of materials and methods and the planning of building sites can improve the rapidity, economy, and durability of many types of construction.

- Robust building methods can be adapted to a wide range of available materials and conditions.

\section{SUMMARY}

Careful design, in harmony with materials science and technology, will produce economical, durable structures. The Romans developed a construction system primarily based on cement and concrete that revolutionized construction throughout the Mediterranean basin. Many of their insights and techniques remain applicable today.

\section{REFERENCES}

Adam, J-P. (1994). Roman building: Materials and techniques, Indiana University Press, Bloomington, Ind.

De Camp, L. S. (1980). The ancient engineers, Ballentine, New York.

Gori, R. (1999). "Theoretical performances of RC elements built at turn of the century." J. of Perf. of Constr. Fac., ASCE, 13(2), 57-66.

Hill, D. (1997). A history of engineering in classical and medieval times, Routledge, New York.

Idorn, G. (1997). Concrete progress: From antiquity to third millennium, Thomas Telford, London.

Malinowsky, R. (1979). "Concretes and mortars in ancient aqueducts." Concrete Int., 1(1), 66-76.

Mehta, P. K., and Langley, W. S. (2000). "Monolith foundation: Built to last a "1000 years." "Concrete Int., 22(7), 27-32.

Palladio, A. (1965). The four books of architecture, I. Ware, translator Dover, New York.

Vitruvius, M. (1960). The ten books on architecture, M. H. Morgan, translator Dover, New York.

White, K. D. (1984). Greek and Roman technology, Cornell University Press, Ithaca, New York. 